\title{
Comparison of fall risk and risk factors between inpatients aged under 65 years and above in an internal medicine clinic
}

Iç hastalıkları servisinde yatan 65 yaş altı ve üstü hastaların düşme riski ve risk faktörlerinin karşılaştırılması

Aslı Kılavuz Delahattin Fehmi Akçiçek $\quad$ S

Ege University, Division of Geriatrics, Department of Internal Medicine, Izmir, Turkey

\begin{abstract}
Aim: The aim of this study is to retrospectively evaluate and compare fall risk and risk factors inpatients aged under 65 years and above in an internal medicine clinic.

Materials and Methods: The study is retrospective and descriptive. The study included 224 patients who were hospitalized for any complaint in the internal medicine clinic of a university hospital between June 2019 and August 2019, and whose data on falls were fully recorded. The sociodemographic variables of the patients, chronic diseases, the number of drugs and the number of risky drugs for falls, and the data of the Itaki fall risk scale were recorded.

Results: The mean age of the patients was $63.18 \pm 17.66(23-95)$ years. A statistically significant difference was found between inpatients aged under 65 years and above in terms of itaki fall risk score, number of chronic diseases, hypertension, diabetes mellitus, heart disease, neurological diseases and number of drugs, number of risky drugs, antidiabetic and antiarrhythmic drugs. A statistically significant difference was found between inpatients aged under 65 years and above in terms of fall risk according to the ltaki fall risk scale $(p=0.038)$.

A statistically significant difference was found between inpatients aged under 65 years and above with a high risk of falling in terms of the number of chronic diseases $(p=0.001)$, presence of diabetes mellitus $(p=0.007)$, presence of hypertension $(p=0.001)$, presence of heart disease $(p=0.002)$, presence of neurological disease $(p=0.03)$, and number of risky drugs $(p=0.01)$.

Conclusion: Falls are an important problem in all age groups. Although fall risk is higher inpatients aged 65 years and above, care should be taken in terms of precautions to be taken to prevent falls in all patients. All risk factors associated with falls should be questioned in all hospitalized patients.
\end{abstract}

Keywords: Elderly, young, fall, fall risk, hospitalized patient.

\section{ÖZ}

Amaç: Bu araştırmanın amacı, bir üniversite hastanesi iç hastalıkları kliniğinde yatan 65 yaş altı ve üstü hastalarda düşme riski ve risk faktörlerinin retrospektif olarak değerlendirilmesi ve karşılaştırılmasıdır.

Gereç ve Yöntem: Araştırma retrospektif, tanımlayıcı tipte olup, araştırmaya Haziran 2019 - Ağustos 2019 tarihleri arasında bir üniversite hastanesinin iç hastalıkları kliniğinde herhangi bir yakınma nedeniyle yatarak tedavi görmüş dosyasında düşme ile ilgili verileri eksiksiz olarak kaydedilmiş olan 224 hasta dahil edilmiştir. Hastaların sosyo-demografik değişkenleri, kronik hastalıkları, hastaneye yatış sırasında kullanılan ilaç sayısı ve düşme için riskli ilaç sayısı gibi klinik verileri ve İtaki düşme riski ölçeği verileri kaydedilmiştir.

\footnotetext{
Corresponding author: Aslı Kılavuz

Ege University, Division of Geriatrics, Department of Internal

Medicine, Izmir, Turkey

E-mail: asli.kilavuz@ege.edu.tr
} 
Bulgular: Hastaların yaş ortalaması 63,18 1 17,66 (23-95) yıldır. 65 yaş altı ve 65 yaş ve üstü hastalar arasında Itaki düşme skoru, kronik hastalık sayısı, kronik hastalık varlığı, hipertansiyon, diabetes mellitus, kalp hastalığı, nörolojik hastalıklar, kullanılan ilaç ve riskli ilaç sayısı, düşme için riskli ilaçlardan antidiyabetik ve antiaritmik ilaçlar açısından istatistiksel olarak anlamlı fark bulunmuştur. Itaki düşme riski ölçeğine göre düşme riski açısından 65 yaş altı ve 65 yaş ve üstü hastalar arasında istatistiksel olarak anlamlı fark bulunmuştur $(p=0,038)$. Yüksek düşme riski olan $<65$ yaş ve $\geq 65$ yaş gruplar karşılaştırıldığında kronik hastalık sayısı $(p=0,001), D M$ varlığı $(p=0,007), H T$ varlığı $(p=$ $0,001)$, kalp hastalığı varlığı $(p=0,002)$, nörolojik hastalık varlığı $(p=0,03)$ ve riskli ilaç sayısı $(p=$ $0,01)$ açısından iki grup arasında istatistiksel olarak anlamlı fark bulunmuştur.

Sonuç: Düşmeler tüm yaş gruplarında önemli bir sorundur. Özellikle 65 yaş ve üstü grupta düşme riski daha yüksek saptanmasına rağmen tüm hastalarda düşmelerin engellenmesi için alınacak önlemler açısından dikkatli olunmalıdır. Hastaneye yatan tüm hastalarda düşmeler ile ilişkili tüm risk faktörleri sorgulanmalıdır.

Anahtar Sözcükler: Yaşlı, genç, düşme, düşme riski, yatan hasta.

\section{INTRODUCTION}

A fall is defined as an individual becoming immobile at a lower level than the current level not led by a force, syncope or a stroke but due to lack of attention and loss of balance $(1,2)$. In order to prevent one of the most frequently observed accidents throughout the world which is falling, safe environments have to be provided ( 3 , 4). It is not possible to clear the fall risk of inpatients however; with the assessment of the fall risk, an efficient prevention program can be constituted which can minimize the risk $(5,6)$. It is indicated that physiological changes and chronical diseases caused by aging increase the risk of falls $(7,8)$. It is also stated that 2.9 to 13 of 1000 hospitalized patients fall (4). More than $80 \%$ of the falls that occur in hospitals are observed in the individuals aged 65 years and above (9). In a study conducted in Turkey, the fall rate of hospitalized patients aged 65 years and above is stated as $10 \%$ (10). Even though falls are common in the older adults, every hospitalized patient encounters the fall risk regardless of their age.

Falls might lead to injuries such as skull fractures, subdural hematoma and massive bleeding as well as delayed recovery, prolonged hospital stay, increased care costs, decreased quality of life, fear of falling, mortality, morbidity, immobility, and early placement in nursing home $(11,12)$.

Intrinsic risk factors for falling include a history of falling, gait and balance disorder, peripheral neuropathy, vestibular impairment, muscle weakness, hearing and vision impairment, incontinence and nocturia, advanced age, orthostatic hypotension, dementia, depression anxiety, polypharmacy, and risky medication use.
Environmental factors, unsuitable footwear and obstacles are also extrinsic risk factors $(4,13)$.

The aim of this study is to retrospectively evaluate and compare fall risk and risk factors inpatients aged under 65 years and above in an internal medicine clinic.

\section{MATERIALS AND METHODS}

The study has been retrospective and descriptive with the sample being 269 patients admitted to and treated by an internal diseases clinic of a university hospital between the dates of JuneAugust 2019 with any type of complaints. Patient files have been scanned retrospectively. Afterwards, 224 patients whose data on falls were fully recorded have been included to the study. The research protocol was approved by the local ethics committee on January 01, 2020 (Approval Number: 22.01.2020/20-1.1T/56). Patients' sociodemographic variables such as age and gender; their clinical data such as chronical diseases, the number of drugs, and risky drugs (psychotropic drugs, sedative hypnotic drugs, antipsychotics, neuroleptics, antidepressants, diuretics, antidiabetics, antiarrhythmics, antihypertensives, chemotherapeutics, laxatives, corticosteroids) they used on the first day of hospitalization and and Itaki fall risk scale scores which is performed on every inpatient have been recorded.

Itaki fall risk scale has been prepared for patients aged 17 years and above. It includes patients' demographics, the reason why the assessment is being administered and lastly the minor and major risk factors. The scale includes a total of 19 risk factor questions; 11 minor and 8 major ones that cause patients to fall. Minor risk factors count 
as 1 point while major risk factors count as 5 points. If the total score of a patient is between 0 4 , the risk is considered as low and if it is 5 or above, the risk is considered as high. Itaki fall risk scale has been published in 2011 by Turkish Health Ministry Head of Performance Administration and Quality Improvement Department (14).

\section{Statistical analyses}

SPSS Statistics Version 22.0 program was used for all statistical analyses and calculations. During the analysis process; percentages, averages, chi square analysis, Fisher's Exact test and Mann Whitney $U$ test have been employed. Kolmogorov-Smirnov test was used to evaluate the normal distribution. Values with a $p$ value $<0.05$ were considered statistically significant.

\section{RESULTS}

224 patients hospitalized in internal diseases clinic have been included in our study. 104
(46.4\%) of the patients were aged under 65 years and $120(53.6 \%)$ of them were aged 65 and above. The mean age of the patients was $63.18 \pm$ 17,66 years (23-95) (aged under 65 years 47.08 $\pm 11.07 ; 65$ and aged above 65 years $77.13 \pm$ 7.47). Sociodemographic and clinically descriptive characteristics of the inpatients were shown in Table 1. 97.8\% of the patients had at least one chronical disease. The most frequently observed chronical diseases were hypertension $(55.8 \%)$, chronical renal failure $(45.5 \%)$ and diabetes mellitus (33.9\%).

A statistically significant difference was found between the two age groups in terms of Itaki fall risk scale score, the number of chronical diseases; the presence of chronical disease, hypertension (HT), diabetes mellitus (DM), heart disease, neurological diseases and other diseases; the number of drugs and risky drugs used, anti-diabetic and antiarrhythmic drugs from risky drugs for falls (Table-1-2).

Table-1. Sociodemographic and clinically descriptive characteristics of the inpatients.

\begin{tabular}{|c|c|c|c|c|}
\hline Characteristic & $\begin{array}{c}\text { Total } \\
\mathrm{n}=224\end{array}$ & $\begin{array}{c}\text { Aged }<65 \\
n=104\end{array}$ & $\begin{array}{c}\text { Aged } \geq 65 \\
n=120\end{array}$ & $\mathbf{p}$ \\
\hline Gender, n (\%) & & & & $0.40^{\mathrm{a}}$ \\
\hline Female & $108(48.2)$ & $47(43.5)$ & $61(56.5)$ & \\
\hline Male & $116(51.8)$ & $57(49.1)$ & $59(50.9)$ & \\
\hline Itaki fall risk scale score ${ }^{*}$ & $10.6 \pm 4.16$ & $8.63 \pm 4.0$ & $11.3 \pm 3.92$ & $0.001^{b}$ \\
\hline Number of chronic diseases ${ }^{\star *}$ & $2(1-6)$ & $2(1-5)$ & $3(1-6)$ & $0.001^{b}$ \\
\hline $\begin{array}{l}\text { Presence of chronic diseases, } \\
\mathrm{n}(\%)\end{array}$ & $207(92.4)$ & $85(42.5)$ & $115(57.5)$ & $0.001^{\star}$ \\
\hline \multicolumn{5}{|l|}{ Chronic Diseases, $n^{\dagger}(\%)^{\dagger \dagger}$} \\
\hline HT & $125(55.8)$ & $41(39.4)$ & $84(70)$ & $0.001^{\mathrm{a}}$ \\
\hline DM & $76(33.9)$ & $24(23.1)$ & $52(43.3)$ & $0.001^{\mathrm{a}}$ \\
\hline Heart Disease & $53(23.7)$ & $13(12.5)$ & $40(33.3)$ & $0.001^{\mathrm{a}}$ \\
\hline CRF & $102(45.5)$ & $51(49)$ & $51(42.5)$ & $0.327^{2}$ \\
\hline Malignancy & $47(21)$ & $23(22.1)$ & $24(20)$ & $0.70^{\mathrm{a}}$ \\
\hline Neurological diseases & $31(13.8)$ & $9(8.7)$ & $22(18.3)$ & $0.036^{\mathrm{a}}$ \\
\hline Others & $86(38.4)$ & $43(41.4)$ & $43(35.8)$ & $0.008^{\mathrm{a}}$ \\
\hline Number of drugs ${ }^{* *}$ & $5(0-16)$ & $4(0-16)$ & $5(0-13)$ & $0.014^{c}$ \\
\hline Number of risky drugs ${ }^{* *}$ & $2(0-8)$ & $1(0-7)$ & $2(0-8)$ & $0.002^{c}$ \\
\hline
\end{tabular}


Table-2. The relationship between the risky drugs and age groups.

\begin{tabular}{lcccc}
\hline Risky drugs & $\begin{array}{c}\text { Total } \\
\mathbf{n}(\%)\end{array}$ & $\begin{array}{c}<65 \text { age } \\
\mathbf{n}(\%)\end{array}$ & $\begin{array}{c}\geq 65 \text { age } \\
\mathbf{n}(\%)\end{array}$ & $\mathbf{p}^{*}$ \\
\hline Psychotropic drugs & $68(30.4)$ & $29(27.9)$ & $39(32.5)$ & 0.45 \\
Anticoagulant drugs & $85(37.9)$ & $33(31.7)$ & $52(43.3)$ & 0.74 \\
Diuretic drugs & $69(30.8)$ & $28(26.9)$ & $41(34.2)$ & 0.24 \\
Antidiabetic drugs & $62(27.7)$ & $22(21.2)$ & $40(33.3)$ & $\mathbf{0 . 0 4}$ \\
Antihypertensive drugs & $69(30.8)$ & $29(27.9)$ & $40(33.3)$ & 0.38 \\
Antiarrhythmic drugs & $25(11.2)$ & $5(4.8)$ & $20(16.7)$ & $\mathbf{0 . 0 0 5}$ \\
Narcotic analgesic drugs & $33(14.7)$ & $16(15.4)$ & $17(14.2)$ & 0.80 \\
\hline
\end{tabular}

"Chi square test has been used.

Table-3. The relationship between age groups and Itaki fall risk scale scores.

\begin{tabular}{cccc}
\hline & $\begin{array}{c}\text { Aged }<65 \\
\mathbf{n}(\%)\end{array}$ & $\begin{array}{c}\text { Aged } \geq 65 \\
\mathbf{n}(\%)\end{array}$ & $\mathbf{p}$ \\
\hline Fall risk, $\mathbf{n}(\%)$ & & & $\mathbf{0 . 0 3 8}$ \\
Low Risk & $12(70.6)$ & $5(29.4)$ & \\
High Risk & $92(44.4)$ & $115(55.6)$ & \\
\hline
\end{tabular}

Table-4. The relationship of patients at high risk of falling with risk factors.

\begin{tabular}{|c|c|c|c|}
\hline Risk factors & $\begin{array}{c}<65 \text { yaş } \\
n(\%)\end{array}$ & $\begin{array}{c}\geq 65 \text { yaş } \\
n(\%)\end{array}$ & $p$ \\
\hline Number of chronic diseases ${ }^{*}$ & $2(0-5)$ & $3(0-6)$ & $0.001^{a}$ \\
\hline Presence of chronic diseases & $80(42.1)$ & $110(57.9)$ & $0.024^{b}$ \\
\hline \multicolumn{4}{|l|}{ Chronic diseases } \\
\hline DM & $24(32)$ & $51(68)$ & $0.007^{b}$ \\
\hline HT & $38(31.4)$ & $83(68.6)$ & $0.001^{b}$ \\
\hline Heart disease & $13(25.5)$ & $38(74.5)$ & $0.002^{b}$ \\
\hline Neurological disease & $8(26.7)$ & $22(73.3)$ & $0.03^{b}$ \\
\hline Number of risky drugs & $76(44.2)$ & $96(55.8)$ & $0.01^{a}$ \\
\hline
\end{tabular}

"The values were given as median (minimum-maximum). ${ }^{\mathrm{a}}$ Mann-Whitney U Test; ${ }^{\mathrm{b}}$ Chi-square Test

According to the Itaki fall risk scale scores, $88.5 \%$ of the patients who were aged under 65 years and $95.8 \%$ of the patients who were aged 65 and above were considered in the high-risk group. A statistically significant difference was found between the two age groups in terms of fall risk according to the Itaki fall risk scale $(p=0.038)$ (Table-3).

When two age groups with high-risk of falling are compared; a statistically significant difference was found between the two age groups in terms of the number of chronic diseases $(p=0.001)$, presence of DM $(p=0.007)$, HT $(p=0.001)$, heart disease $(p=0.002)$, neurological disease $(p=0.03)$, and number of risky drugs $(p=0.01)$ (Table-4).

A statistically significant difference was found between the two age groups in terms of consciousness open / not cooperative, visual impairment, need for physical support and chronical diseases (Table-5). 
Table-5. The relationship between the risk factors in the Itaki fall risk scale and the age groups.

\begin{tabular}{|c|c|c|c|}
\hline Risk Factors & $\begin{array}{l}<65 \text { yaş } \\
n=104\end{array}$ & $\begin{array}{l}\geq 65 \text { yaş } \\
n=120\end{array}$ & $\mathbf{p}$ \\
\hline $\begin{array}{l}\text { Consciousness open, not } \\
\text { cooperative }\end{array}$ & $2(14.3)$ & $12(85.7)$ & $0.013^{*}$ \\
\hline History of falls in the last month & $3(30)$ & $7(70)$ & $0.35^{*}$ \\
\hline \multicolumn{4}{|l|}{ Vision } \\
\hline Poor vision & $11(26.8)$ & $30(73.2)$ & $0.005^{*}$ \\
\hline Visual impairment & $2(50)$ & $2(50)$ & $1.00^{* *}$ \\
\hline Need for physical support & $9(28.1)$ & $23(71.9)$ & $0.02^{*}$ \\
\hline Urinary / Fecal incontinence & $2(28.6)$ & $5(71.4)$ & $0.45^{*}$ \\
\hline Use of risky drugs in the last week & $85(45.2)$ & $103(54.8)$ & $0.40^{*}$ \\
\hline \multicolumn{4}{|l|}{ Medical equipment maintenance } \\
\hline Three and more & $45(45)$ & $55(55)$ & $0.70^{*}$ \\
\hline Less than three & $32(50)$ & $32(50)$ & $0.50^{*}$ \\
\hline Orthostatic hypotension & 0 & 1 & $1.00^{*}$ \\
\hline Dizziness & 0 & 3 & $0.25^{*}$ \\
\hline Loss of balance & $10(34.5)$ & $19(65.5)$ & $0.17^{*}$ \\
\hline Use of more than four drugs & $15(44.1)$ & $19(55.9)$ & $0.77^{*}$ \\
\hline Presence of chronic diseases & $85(42.5)$ & $115(57.5)$ & $0.001^{*}$ \\
\hline Physical disability & $1(16.7)$ & 5 (83.3) & $0.22^{* *}$ \\
\hline
\end{tabular}

"Chi square test, "Fisher's Exact Test

\section{DISCUSSION}

Falls are a serious problem that increase mortality and morbidity and lead to a decrease in physical, psychological and social life satisfaction due to complications. Most of the factors that lead to falls can be prevented. Therefore, describing falls and identifying, eliminating or preventing risk factors would decrease the frequency of falling.

The literature indicates that falls are the most frequently observed in physical treatment and rehabilitation, internal diseases, geriatrics and neurology clinics $(10,15-17)$. In the studies conducted by Kerzman et al. (16), Krauss et al. (18) and Fischer et al. (19), among inpatients, the ages between 50-70 have been determined to be risky. The literature has also indicated the age of 65 and above to be a risk factor for falling $(17,18$, 20-23). In a study conducted with a group of patients hospitalized in an internal diseases' clinic have found a statistically significant relationship between old age and fall risk (24) as we have found in our study. In a study conducted with inpatients from neurology and neurosurgery clinics have found that risk of falling is higher for patients aged 60 and above than for patients below 60 , even though the difference is not statistically significant (10). Coherent with this study, we have observed that the fall risk inpatients aged 65 and above is higher and found a statistically significant difference between the two age groups in their fall risk. Difference between the results can be explained by the characteristics of the patients included in the study and the scales used to measure fall risk.

When two genders are compared in terms of their fall risk, some studies have reported a difference while some studies have not $(16,25-31)$. Difference between the results can be explained with the difference in the proportion of each gender observed in the samples of the studies. In a study, it has been found that among a high-risk of falling inpatients, $56.7 \%$ are men (32). In our study, among patients at a high-risk of falling, $50.7 \%$ have found to be men. Apart from that, we have found that among the patients aged under 65 , men have a higher risk of falling while among the patients aged 65 and above women have a higher risk of falling. However, there has not been found a statistically significant difference between the two age groups. 
In a study, it has been found that while $13.7 \%$ of the inpatients have experienced 1-2 falls in the last three months; $1.5 \%$ have experienced 3 or more falls (32). In the literature, a history of falling is considered as a risk factor in fall risk assessments $(17,21,33)$. It has also been found that $20.9 \%$ of the inpatients had a history of falling in the last three months and that there was a statistically significant relationship between the high risk of falling and a history of falling in the last three months (10). The same significant relationship has been found in other studies as well $(34,35)$. We have also found that $4.5 \%$ of our patients had a history of falling in the last month and no statistically significant relationship was found between the risk of falling and the history of falling in the last 1 month. The reason for this can be the Itaki fall risk scale asking whether a history of falling in the last month is one of the minor risk factors for falling or not. If it asked whether a history of falling in the last three months or a year rather than a month was one of the minor risk factors, then the results could have been different.

The presence of chronical diseases causes people to lose their moving abilities which creates a risk for falling $(36,37)$. Chronic diseases increase the risk of falling $(13,37,38)$. Also, many studies have found a significant relationship between the presence of chronical diseases in older adults and a high-risk of falling $(37,39-40)$. We as well have found a statistically significant difference between the two age groups with a high risk of falling in terms of presence and number of chronic diseases.

The frequency of falls in patients with diabetes was $39 \%$ and it is observed the most in older adults (41). We have also found a statistically significant difference between the two age groups with a high risk of falling in terms of the presence of DM. It is indicated that the most frequent diagnosis the patients who fall get was hypertension (86\%) $(18,25,42)$. In our study, we as well have found that the most frequent diagnosis the patients got to be hypertension $(55.8 \%)$ and that there is a statistically significant relationship between hypertension and a high risk of falling in the group aged 65 and above. The reason for that is thought to be the increasing frequency of incidence of hypertension in the patients with increasing age (43). Heart diseases which is observed frequently in older patients have also been indicated to be related with a high risk of falling $(37,39)$. Coherent with this finding, we also have found a statistically significant difference between two age groups with high-risk of falling in the presence of heart diseases.

One of the common side effects of drugs is falls and there has been found a relationship between polypharmacy and falls (44). Kallin (21) and Reifkolh et al. (45) have indicated that use of four or more drugs increase the risk of falling. In some studies polypharmacy has shown to be related with falls $(46,47)$ while in other studies this relationship has not been observed (37). In our study, there has not been found a significant difference in use of four and more drugs and number of drugs between the two age groups with a high-risk of falling. However, when all the age groups were observed, an increase in the number of drugs used has been found to be related with an increase in the risk of falling. This result leads to the questioning of whether the number of drugs used by a patient influences the risk of falling regardless of age or not.

According to the results of a meta-analysis, it has been indicated that psychotropic drugs are related with the increase in the risk of falling, anticonvulsants and antiarrhythmic drugs can lead to an increase in the risk of falling, chronic use of antihypertension drugs are presumably not related with an increase in the risk of falling and cardiac and narcotic analgesic drugs are not related with an increase in the risk of falling (45, $48,49)$. In our study, there was a significant difference in terms of number of high-risk drugs between the two age groups with a high-risk of falling. It has been found that the number of risky drugs used is higher in high risk patients aged 65 years and over. It has been found that the number of risky drugs used was higher inpatients aged 65 years and above with a high-risk of falling.

The using physical support for walking, and poor vision are considered as risk factors for falls in older adults (21). Coherent with this finding, we as well have found that poor vision and the using physical support for walking which both are risk factors have been observed more frequently in older patients in comparison to younger patients. In the literature, the presence of changes in the level of consciousness is also considered as the risk factor for falling $(16,17,19,50)$. We have found that the presence of changes in the level of consciousness which affects the risk of falling is 
observed more frequently in the group aged 65 and above.

The limitations of the study include the various individuals who have administered the Itaki fall risk scale to the patients and the lack of sociodemographic data in the files of some patients.

\section{CONCLUSION}

As a consequence, with the assessment of the risk factors for falling in the patients aged under and above 65, some differences have been detected however, falls are an important problem in all age groups. Even though the risk of falling has been found to be higher in the group aged 65 and above, precautions for avoiding patients from falls must be taken carefully. Every hospitalized patient must be questioned about their risk factors for falls. Our study was carried out in order to determine the deficiencies in the precautions related to falls that will occur in the patients hospitalized in the internal medicine service and to contribute to the creation of protocols for preventing falls in the hospitals of the patients.

Conflict of Interest: The authors declare that there is no conflict of interest.

No funds, grants, or other support was received.

\section{References}

1. Alexander BH, Rivara FP, Wolf ME: The Cost and Frequency of Hospitalization for Related-Injuries in Older Adults. Am J Public Health 1992; 82: 1020-3.

2. Myers H. Hospital fall risk assessment tools: A critique of the literature. Int J Nurs Pract 2003; 9 (4): 223-35.

3. Karaman Özlü Z, Yayla A, Özer N, Gümüș K, Erdağı S, Kaya Z. Risks of Falling in Surgical Patients. Kafkas J Med Sci 2015; 5 (3): 94-9. doi: 10.5505/kjms.2015.19870.

4. Oliver D, Daly F, Martin FC, et al. Risk factors and risk assessment tools for falls in hospital in-patients: a systemic review. Age Ageing 2004; 33 (2): 122-30.

5. Oliver D, Britton M, Seed P, Martin FC. Development and evaluation of evidence based risk assessment tool (STRATIFY) to predict which elderly inpatients will fall: case-control and cohort studies. British Medical Journal 1997; 315: 1049-53.

6. Close J, Ellis M, Hooper R, Glucksman E, Jackson S, Swift C. Prevention of falls in the elderly trial (PROFET): a randomised controlled trial. Lancet 1999; 353: 93-7.

7. Berke D, Aslan FE. Cerrahi hastalarını bekleyen bir risk: düşmeler, nedenleri ve önlemler. Anadolu Hemşirelik ve Sağlık Bilimleri Dergisi 2010; 13: 72-4.

8. Naharcı Mi, Doruk H. Yaşlı Popülasyonda Düşmeye Yaklaşım. TAF Preventive medicine Bulletin 2009; 8 (5): 437-44.

9. Healey F. A Guide on How to Prevent Falls and İjury in Hospital. Nursing Older People 2010; 22 (9): 16-22.

10. Savcı C, Kaya H, Acaroğlu R, Kaya N, Bilir A, Kahraman H, Gökerler N. Nöroloji ve Nöroşirürji Kliniklerinde Hastaların Düşme Riski ve Alınan Önlemlerin Belirlenmesi. Maltepe Üniversitesi Hemşirelik Bilim ve Sanatı Dergisi 2009; 3: 19-25.

11. Bates DW, Pruess K, Souney P, Platt R. Serious falls in hospitalized patients: correlates and resource utilization. Am J Med 1995; 99 (2): 137-43.

12. Hendrich A, Nyhuis A, Kippenbrock T, Soja ME. Hospital falls: developing of a predictive model for clinical practice. Applied Nursing Research 1995; 8: 129-39.

13. Tinetti ME, Doucette J, Claus E, Marottoli RA. Risk factors for serious injury during falls by older persons in the community. J Am Geriatr Soc 1995; 43: 1214-21.

14. T.C. Sağık Bakanlığı Sağlık Hizmetleri Genel Müdürlüğü İtaki Düşme Riski Ölçeği (2017). https://kalite.saglik.gov.tr/TR,13486/itaki-dusme-riskiolcegi.html. Erişim Tarihi: 01.02.2020.

15. Nyberg L, Gustafson Y. Patient Falls in Stroke Rehabilitation. Stroke 1995; 26: 838-42.

16. Kerzman H, Chetrit A, Brin L, Toren O. Characteristics of Falls in Hospitalized Patients. Journal of Advanced Nursing 2004; 47 (2): 223-9.

17. Schwendimann R, De Geest S, Milisen K. Characteristics of In-Patient Falls in Different Hospital Departments. in: Patient falls: a key issue in patient safety in hospitals Zürih. 2006; 32-49. [Cited 10.11.2020]. Available from: https://core.ac.uk/download/pdf/18233823.pdf. 
18. Krauss M, Evanoff B, Hitcho E, Ngugi K, Dunagan WC, Fischer I, Birge S, Johnson S, Costantinou E, Fraser VJ. A Case-control study of patient, medication and care-related risk factors for inpatient falls. Journal of General Internal Medicine 2005; 20: 116-22.

19. Fischer, ID, Krauss, MJ, Dunagan, WC, Birge, S, Hitcho, E, Johnson, S, Costantinou, E, Fraser, VJ. Patterns and predictors of inpatient falls and fall-related Injuries in a large academic hospital. Infection Control and Hospital Epidemiology 2005; 26 (10): 822-7.

20. Hitcho EB, Krauss MJ, Birge S, Dunagan WC, Fischer I, Johnson S, Nast PA, Costantinou R, Fraser VJ. Characteristics and circumstance of falls in a hospital setting. Journal of Internal Medicine 2004; 19: 732-9.

21. Kallin, K. Falls in older people in geriatric care setting, predisposing and precipitating factors. Aging Clinical and Experimental Research 2004; 16 (4): 6-270.

22. Choi, H, Trent, R, Nishita, C, Pynoos, J. (2007). Falls Among Older Adults in California: Public Health Surveillance Issues. www.stopfalls.org.

23. O'Hagan, C, \& O'Connell, B. The relationship between patient blood pathology values and patient falls in an acute-care setting: A retrospective analysis. International Journal of Nursing Practice 2005; 11: 161-8.

24. Mollaoğlu M, Fertelli T, Tuncay FÖ. Dahili Kliniklerde Yatan Hastalarda Düşme Riski ve Alınan Önlemlerin Incelenmesi. TAF Preventive Medicine Bulletin 2013; 12 (1): 27-34.

25. Karataş KG, Maral I. Ankara Gölbaşı İlçesinde Geriatrik Popülasyonda 6 Aylık Dönemde Düşme Sıkığı ve Düşme İçin Risk Faktörleri. Türk Geriatri Dergisi 2001; 4 (4): 152-8.

26. Hendrich AL, Bender PS, Nyhuis A. Validation of Hendrich II Fall Risk Model: A Large Concurrent Case/Control Study of hospitalized Patients. Applied Nursing Research 2003; 16 (1): 9-21.

27. Gemalmaz A, Dişçigil G, Başak O. Huzurevi sakinlerinin yürüme ve denge durumlarının değerlendirmesi. Türk Geriatri Dergisi 2004; 7 (1): 41-4.

28. Özdemir L, Akdemir N, Akyar İ. Hemşireler için geliştirilen yaşlı değerlendirme formu ve geriatrik sorunlar. Türk Geriatri Dergisi 2005; 8 (2): 94-100.

29. Yeşilbakan UÖ, Karadakovan A. Narlıdere dinlenme ve bakımevinde yaşayan yaşlı bireylerdeki düşme sıklığı ve düşmeyi etkileyen faktörleri. Türk Geriatri Dergisi 2005; 8 (2): 72-7.

30. Atman CÜ, Dinç G, Oruçoğlu A, Oğurlu H, Ecebay A. Manisa Muradiye Sağlık Ocağı Bölgesinde Yaşı̆ılarda Kaza Sıklığı ve Kaza İle İlişkili Faktörler. Türk Geriatri Dergisi 2007; 10 (2): 83-7.

31. Oyur Çelik G, Zıngal H. Beyin Cerrahisi Kliniğinde Yatan Hastaların Düşme Risklerinin ve Alınan Önlemlerin Belirlenmesi. İzmir Kâtip Çelebi Üniversitesi Sağlık Bilimleri Fakültesi Dergisi 2016; 1 (1): 7-11.

32. Uysal Madak K. Bir üniversite hastanesindeki hastaların düşme risk düzeylerinin ve düşme önleme uygulamalarının değerlendirilmesi. Yüksek Lisans Tezi, Dokuz Eylül Üniversitesi, 2010.

33. Williams, CR, Rush, KL, Bendyk, H, Patton, LM,Chamberlain, D, Sparks, T. Spantanburg Fall Risk Assessment Tool: A Simple Three-step Process". Nursing Research 2007; 20: 86-93.

34. Evans D, Hodgkinson B, Lambert N, Wood J. Falls risk factors in the hospital setting: A systematic review. International Journal of Nursing Practice 2001; 7 (1): 38-45.

35. Vassallo M, Vignaraja R, Sharma JC, Briggs R, Allen $S$. The relationship of falls to injury among hospital in patient. International Journal of Clinical Practice 2005; 59: 17.

36. Akın B, Emiroğlu ON. Evde Yaşayan Yaşılıarda Mobilitede Yeti Yitimi ve Illişkili Faktörlerin Incelenmesi. Türk Geriatri Dergisi 2003; 6 (2); 59-67.

37. Lawlor DA, Patel R, Ebrahim S. Association between falls in elderly women and chronic diseases and drug use: cross sectional study. BMJ 2003; 327: 712-7.

38. O'Loughlin JL, Robitaille Y, Boivin JF, Suissa S. Incidence of and risk factors for falls and injurious falls among the community-dwelling elderly. Am J Epidemiol 1993; 137: 342-54.

39. Lee PG, Cigolle C, Blaum C. The Co-Occurrence of Chronic Diseases and Geriatric Syndromes: The Health and Retirement Study. J Am Geriatr Soc 2009; 14: 511-6. doi: 10.1111/j.1532-5415.2008.02150.x.

40. Shumway-Cook A, Ciol MA, Hoffman J, Dudgeon BJ, Yorkston K, Chan L. Falls in the medicare population: Incidence, associated factors, and Impact on health care. Phys Ther 2009; 14: 324-32. doi: 10.2522/ptj.20070107.

41. Tilling LM, Darawil K, Britton M.Falls as a complication of diabetes mellitus in older people. Journal of Diabetes and its Complications 2006; 20 (3): 158-62.

42. Davenport, RD, Vaidean, GD, Jones, CB, Chandler, M, Kessler, LA, Mion, LC, Shorr, RI. Falls Following Discharge After an in-Hospital Fall. BMJ 2009; 9: 53: 1-7. 
43. Kearney PM, Whelton M, Reynolds K, Muntner P, Whelton PK, He J. Global burden of hypertension: analysis of worldwide data. Lancet 2005; 365: 217-23.

44. Field TS, Gurwitz JH, Avorn, J. Risk factors for adverse drug events among nursing home residents. Archive Internal Medicine 2001; 161 (13): 1629-34.

45. Reifkohl, EZ, Bieber, HL, Burlingame, MB, Lowenthal, DT. Medications and falls in the elderly: A rewiew of the evidence and practical considerations. Pharmacy \& Therapeutics 2003; 28 (11): 724-34.

46. Campbell AJ, Borrie MJ, Spears GF. Risk factors for falls in a community-based prospective study of people 70 years and older. J Gerontol 1989; 44: M112-7.

47. Robbins AS, Rubenstein LZ, Josephson KR, Schulman BL, Osterweil D, Fine G. Predictors of falls among elderly people. Results of two population-based studies. Arch Intern Med 1989; 149: 1628-33.

48. Leipzig RM, Cumming RG, Tinetti ME. Drugs and falls in older people: A systematic review and metaanalysis, Part I. Psychotropic drugs. J Am Geriatr Soc 1999; 47: 30-9.

49. Leipzig RM, Cumming RG, Tinetti ME. Drugs and falls in older people: A systematic review and metaanalysis, Part II. Cardiac and analgesic drugs. J Am Geriatr Soc 1999; 47: 40-50.

50. Fonda D, Cook J, Sandler V, Ailey M. Sustained reduction in serious fall-related injuries in older people in hospital. Medical Journal of Australia 2006;168 (8): 379-82. 